May 2002 • NREL/CP-520-31474

\title{
Wide-Gap Thin Film Si $n-i-p$ Solar Cells Deposited by Hot-Wire CVD
}

\section{Preprint}

Q. Wang and E. Iwaniczko

National Renewable Energy Laboratory

J. Yang, K. Lord, and S. Guha United Solar Systems Corporation

K. Wang and D. Han

University of North Carolina at Chapel Hill

To be presented at the $29^{\text {th }}$ IEEE PV Specialists Conference New Orleans, Louisiana May 20-24, 2002
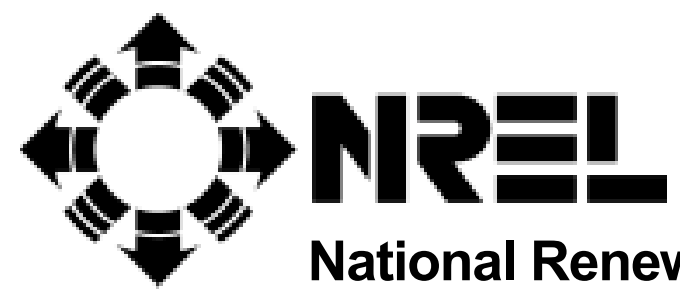

National Renewable Energy Laboratory

1617 Cole Boulevard Golden, Colorado 80401-3393

NREL is a U.S. Department of Energy Laboratory Operated by Midwest Research Institute $\bullet$ Battelle $\bullet$ Bechtel Contract No. DE-AC36-99-G010337 


\section{NOTICE}

The submitted manuscript has been offered by an employee of the Midwest Research Institute (MRI), a contractor of the US Government under Contract No. DE-AC36-99G010337. Accordingly, the US Government and MRI retain a nonexclusive royalty-free license to publish or reproduce the published form of this contribution, or allow others to do so, for US Government purposes.

This report was prepared as an account of work sponsored by an agency of the United States government. Neither the United States government nor any agency thereof, nor any of their employees, makes any warranty, express or implied, or assumes any legal liability or responsibility for the accuracy, completeness, or usefulness of any information, apparatus, product, or process disclosed, or represents that its use would not infringe privately owned rights. Reference herein to any specific commercial product, process, or service by trade name, trademark, manufacturer, or otherwise does not necessarily constitute or imply its endorsement, recommendation, or favoring by the United States government or any agency thereof. The views and opinions of authors expressed herein do not necessarily state or reflect those of the United States government or any agency thereof.

Available electronically at http://www.osti.gov/bridge

Available for a processing fee to U.S. Department of Energy and its contractors, in paper, from:

U.S. Department of Energy

Office of Scientific and Technical Information

P.O. Box 62

Oak Ridge, TN 37831-0062

phone: 865.576 .8401

fax: 865.576.5728

email: reports@adonis.osti.gov

Available for sale to the public, in paper, from:

U.S. Department of Commerce

National Technical Information Service

5285 Port Royal Road

Springfield, VA 22161

phone: 800.553 .6847

fax: 703.605.6900

email: orders@ntis.fedworld.gov

online ordering: http://www.ntis.gov/ordering.htm

Printed on paper containing at least $50 \%$ wastepaper, including $20 \%$ postconsumer waste 


\title{
WIDE-GAP THIN FILM SI $n$-i-p SOLAR CELLS DEPOSITED BY HOT-WIRE CVD
}

\author{
Qi Wang, ${ }^{1}$ Eugene Iwaniczko, ${ }^{1}$ Jeffrey Yang, ${ }^{2}$ Kenneth Lord, ${ }^{2}$ Subhendu Guha, ${ }^{2}$ Keda Wang, ${ }^{3}$ and Daxing $\mathrm{Han}^{3}$ \\ ${ }^{1}$ National Renewable Energy Laboratory (NREL) 1617 Cole Blvd., Golden, CO 80401 \\ ${ }^{2}$ United Solar Systems Corp., (USSC) Troy, MI 48084 \\ ${ }^{3}$ Department of Physics and Astronomy, University of North Carolina at Chapel Hill, Chapel Hill, NC 27599
}

\begin{abstract}
High-voltage wide bandgap thin-film Si $n-i-p$ solar cells have been made using the hot-wire chemical vapor deposition (HWCVD) technique. The best open-circuit voltage $\left(\mathrm{V}_{\mathrm{oc}}\right)$ has exceeded $0.94 \mathrm{~V}$ in solar cells using HWCVD in the entire $n-i-p$ structure. A $V_{\text {oc }}$ of $0.97 \mathrm{~V}$ has been achieved using HWCVD in the $n$ and $i$ layers and plasma-enhanced (PE) CVD for the $p$ layer. The high voltages are attributed to the wide-gap $i$ layer and an improved $p / i$ interface. The wide-gap $i$ layer is obtained by using low substrate temperatures and sufficient hydrogen dilution during the growth of the $i$ layer to arrive at the amorphous-to-microcrystalline phase transition region. The optical band gap $\left(\mathrm{E}_{04}\right)$ of the $i$ layer is found to be 1.90 $\mathrm{eV}$. These high-voltage cells also exhibit good fill factors exceeding 0.7 with short-circuit-current densities of 8 to 10 $\mathrm{mA} / \mathrm{cm}^{2}$ on bare stainless steel substrates. We have also carried out photoluminescence (PL) spectroscopy studies and found a correlation between $V_{o c}$ and the $P L$ peak energy position.
\end{abstract}

\section{INTRODUCTION}

Open-circuit voltage $\left(\mathrm{V}_{\mathrm{oc}}\right)$ is the voltage measured between two terminals of a solar cell under illumination at zero current. It roughly measures or relates to the quasiFermi energy between electrons and holes of an absorber layer under illumination. Improvements in $\mathrm{V}_{\mathrm{oc}}$ can certainly benefit the performance of a solar cell if other characteristics are not compromised. Despite major efforts [1-3], fundamental understanding on how to further improve $V_{\text {oc }}$ remains a major issue. Experimentally, many research groups have achieved high $V_{\text {oc }}$ 's $\sim 1 \mathrm{~V}$ by inserting a thin buffer layer between the $p$ and $i$ layer, such as a wide-gap a-SiC: $\mathrm{H}$ or a-SiO:H layer, hydrogen-diluted a-Si:H $i$ layer near the amorphous-to-microcrystalline transition, or a wide-gap conductive $\mathrm{H}$-diluted $p$ layer, or using a microcrystalline $p$ layer [4-7]. In general, the limitation of $V_{\text {oc }}$ can be attributed to the bulk $i$ layer, doped layers, and interfaces. However, in high $\mathrm{V}_{\mathrm{oc}}$ cells, it is difficult to separate out effect from each factor, thus making further improvements even more challenging.

For solar cells fabricated by the hot-wire (HW) CVD technique, the reported best initial $\mathrm{V}_{\mathrm{Oc}}$ is $0.92 \mathrm{~V}$ in a hybrid devices [8] where the $n$ and $i$ layers were deposited by HWCVD, and $0.88 \mathrm{~V}$ for all-HW solar cells [9] that the $n, i$, and $p$ layers were entirely made using HWCVD. Many groups have achieved $\mathrm{V}_{\text {oc }}$ 's just below $0.90 \mathrm{~V}$ for their best HW solar cells [10-12]. The large difference when compared to the PECVD solar cells of $1.05 \mathrm{~V}$ motivates us to search for high $V_{\text {oc }} \mathrm{HW}$ solar cells. When successful, the high deposition rate, which is one of the advantages of HWCVD, can be finally utilized.

In this paper, we present experimental data for high $\mathrm{V}_{\text {oc }}$ a-Si:H solar cells where at least the $i$ layer was deposited using the HWCVD technique. We focus on optimizing the wide-gap $i$ layer using $\mathrm{H}$-dilution such that the material is near the phase transition from amorphousto-microcrystalline silicon at a high deposition rate of 10 Ås.

\section{EXPERIMENTAL DETAILS}

High $V_{\text {oc }}$ solar cells were developed in the NREL load-locked two-chamber HWCVD T-system. The details of this system were reported elsewhere [13]. We use a $S S / n-i-p / I T O$ configuration in all solar cells, where substrates were bare stainless steel (SS). For all-HW solar cells, a $300-\AA$ n-layer was first deposited at $300^{\circ} \mathrm{C}$ in the dopant chamber. Then an $1800-\AA$ (except for the thickness- dependent study) i-layer was deposited under various conditions to search for high $\mathrm{V}_{\text {oc. }}$. The sample then was transferred back to the dopant chamber for a brief atomic $\mathrm{H}$ treatment before depositing an $60-\AA \AA$ buffer layer. Finally, a $140-\AA$ p-layer was deposited at $150^{\circ} \mathrm{C}$. The solar cell was completed by evaporating $600-\AA \AA$ indium tin oxide (ITO) top contacts, with dot areas of $0.05 \mathrm{~cm}^{2}$. For hybrid solar cells, the $n$ and $i$ layers are deposited at the optimized conditions by HWCVD at NREL, then the unfinished solar cell-sealed in $\mathrm{N}_{2}$ filled bag-was sent to United Solar for depositing the $p$ layer and the top ITO contact. The cell has a total area of $0.26 \mathrm{~cm}^{2}$ defined by circular ITO top contact. The evaluation of solar cells was done at NREL and United Solar using standard AM 1.5 condition at $25^{\circ} \mathrm{C}$.

The $i$-layer optimization was performed using the above device configuration. The growth conditions, such as substrate temperature, hydrogen dilution, chamber pressure, and thickness, were varied to search for high $\mathrm{V}_{\text {oc }}$ solar cells. These conditions were near the threshold of the transition from amorphous-to-microcrystalline silicon. The deposition rate for $\mathrm{H}$-diluted $i$ layers is about $10 \mathrm{~A} / \mathrm{s}$. The $\mathrm{H}$-dilution ratio $(R)$ of $\mathrm{H}_{2}$ to $\mathrm{SiH}_{4}$ is one of the critical parameters that control the phase of the thin film Si.

Photoluminescence was measured on all-HWCVD 
solar cells using the 514.5-nm, and 632.8-nm light beams from $\mathrm{Ar}^{+}$and $\mathrm{HeNe}$ lasers respectively with power density of $30-100 \mathrm{~mW} / \mathrm{cm}^{2}$ for the PL excitation. Samples were mounted on a cold stage which provides a temperature range from 80 to $300 \mathrm{~K}$. The PL spectra were analyzed using a grating monochromator and detected by a $\mathrm{LN}_{2}-$ cooled $\mathrm{Ge}$ detector.

\section{RESULTS AND DISCUSSIONS}

Figure 1 shows the effect of hydrogen dilution of $i$ layers on $V_{\text {oc }}$ (solid symbols) and FF (open symbols) for all $\mathrm{HW}$ solar cells fabricated at NREL. First, we observed that hydrogen dilution increases $V_{\text {oc }}$. For example, $V_{\text {oc }}$ has reached over $0.90 \mathrm{~V}$ for $R=1.8$, which is greater than the best $\mathrm{V}_{\text {oc }}$ of $0.88 \mathrm{~V}$ for the solar cell without $\mathrm{H}$-dilution [8]. Symbol * represents the early data for comparison. We also observe that $\mathrm{V}_{\text {oc }}$ improved by as much as $20 \mathrm{mV}$ with a slight increase of $R$ by 0.45 at $R=2.25$. Further increases of $R$ cause $V_{\text {oc }}$ to decline. We chose $R=2.25$ as the optimized $\mathrm{H}$-dilution. With increasing $R$, the i-layer has a tendency to become $\mu \mathrm{c}-\mathrm{Si}$. It is worth noting that the typical $\mathrm{V}_{\text {oc }}$ of $\mu \mathrm{c}-\mathrm{Si}$ solar cells is less than $0.60 \mathrm{~V}$. All solar cells have good FFs that are greater than 0.70 .

Despite having only a few samples, the very sensitive behavior of $V_{\text {oc }}$ to $R$ agrees well with the general trend that thin-film Si changes the phase transition from amorphous to microcrystalline silicon with increasing $R$, which was concluded from the film study [14]. We believe that the wider-gap $i$-layer that is near or on the edge of the phase transition one of the factors leading to the high $\mathrm{V}_{\text {oc. }}$. The optical bandgap $\left(\mathrm{E}_{04}\right)$ of the film grown on the glass under the same condition of high $\mathrm{V}_{\text {oc }}$ solar cells shows a higher value $(1.90 \mathrm{eV})$ than the one $(1.88 \mathrm{eV})$ without $\mathrm{H}$-dilution. The 20-meV increase in $\mathrm{E}_{04}$ cannot explain more than 20$\mathrm{mV}$ increases in $\mathrm{V}_{\mathrm{oc}}$ assuming that the $\mathrm{V}_{\mathrm{oc}}$ has a linear relationship with bandgap. Other factors must be taken into account such as the effect of the $\mathrm{H}$-diluted $i$ layer on the $p$ and $i$ interface and the $p$ layer growth afterward.

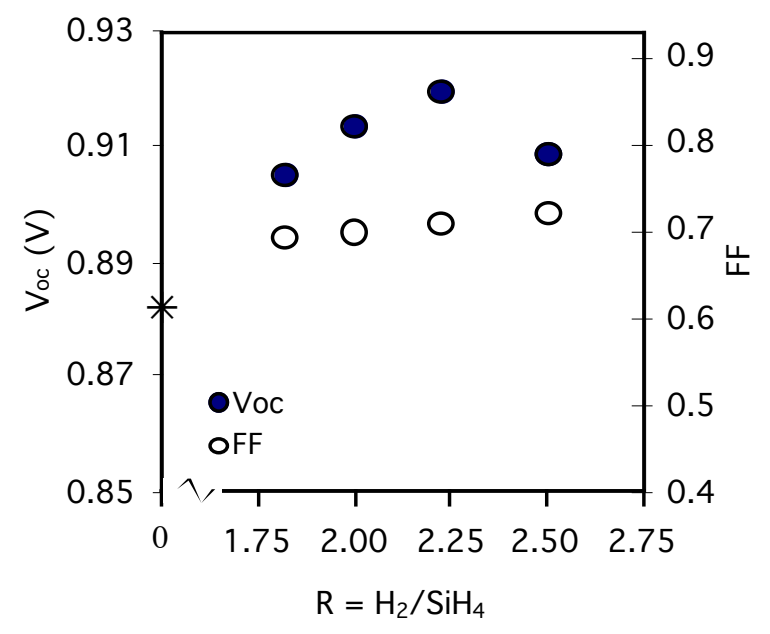

Fig. 1. $V_{o c}$ and FF dependence on the hydrogen dilution of the i-layer. The scale of $y$-axis is magnified.

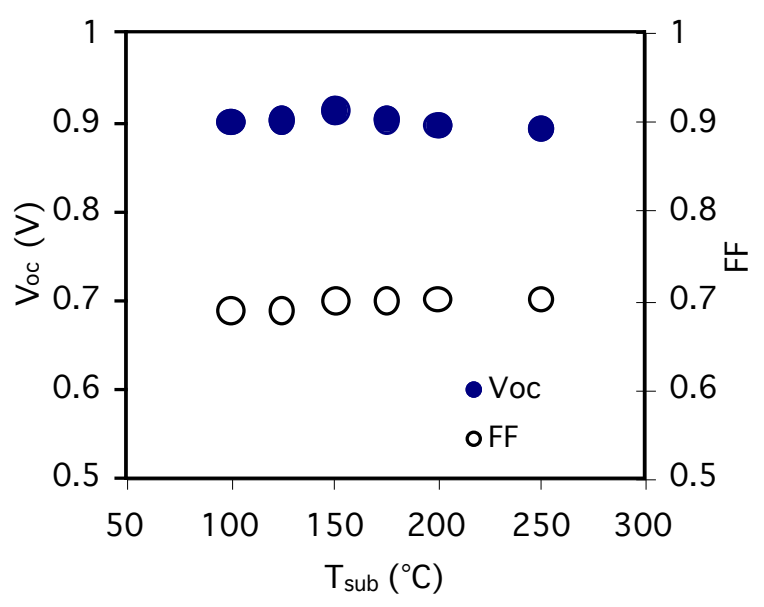

Fig. 2. $V_{o c}$ and $F F$ dependence on the substrate temperature for the solar cells with i-layer with $\mathrm{H}$-dilution.

Finally, we concluded that the outcome of increasing $\mathrm{V}_{\mathrm{oc}}$ using "finite-tuned" $\mathrm{H}$-dilution, which is near the phase transition, is similar for solar cells fabricated by the HWCVD technique or the PECVD method, despite the different growth method and deposition rate.

Figure 2 shows the dependence of solar cell performance on substrate temperature. All HW solar cells have an $\mathrm{H}$-diluted $i$ layer with $R=2.25$, and the temperature changes from $100^{\circ} \mathrm{C}$ to $250^{\circ} \mathrm{C}$. The temperatures used in the figure are the starting temperature and are monitored using two thermocouples (TC) placed inside the chamber. During the deposition, the radiation from the hot-wire heats up the film and substrate. Therefore, the final temperatures, which depend on the deposition time and other factors, are higher than the starting one. Fortunately, most $i$ layer depositions are done within 2-3 minutes and the TC reading changes about $20^{\circ}-30^{\circ} \mathrm{C}$. However, the real temperature at the surface of the film is difficult to determine because of the complicated absorption, heat dissipation, type of substrate, and deposition conditions.

We initially grow the $\mathrm{H}$-diluted solar cells at $250^{\circ} \mathrm{C}$. The solar cell has a reasonable high $\mathrm{V}_{\text {oc }}$ of $0.89 \mathrm{~V}$ and $\mathrm{FF}$ of 0.70 . To search for other solar cells with high $\mathrm{V}_{\mathrm{oc}}$, we decreased the substrate temperature from $250^{\circ} \mathrm{C}$ to $100^{\circ} \mathrm{C}$. In general, the results suggest that the substrate temperature does not dramatically impact solar cell performance. However, it does cause about $20-\mathrm{mV}$ increase of $\mathrm{V}_{\mathrm{oc}}$ at $150^{\circ} \mathrm{C}$ compared to the solar cell at $250^{\circ} \mathrm{C}$. Also, at $100^{\circ} \mathrm{C}$, we can make a solar cell with $\mathrm{V}_{\text {oc }}$ slightly higher than $0.90 \mathrm{~V}$. We chose $150^{\circ} \mathrm{C}$ as the optimized temperature.

To closely examine the effect of $i$ layer to the solar cell performance, we selected PL spectra measurements on the same set of solar cells in Figure 2. Most PL signal is believed to come from the $i$-layer, and much less from ITO and thin $p$-layer. Figure 3 shows the correlation between $\mathrm{PL}$ peak energy position at $80 \mathrm{~K}$ and $\mathrm{V}_{\mathrm{oc}}$ on the same solar cells. In a range of $V_{o c}$ from 0.893 to $0.914 \mathrm{~V}$, 


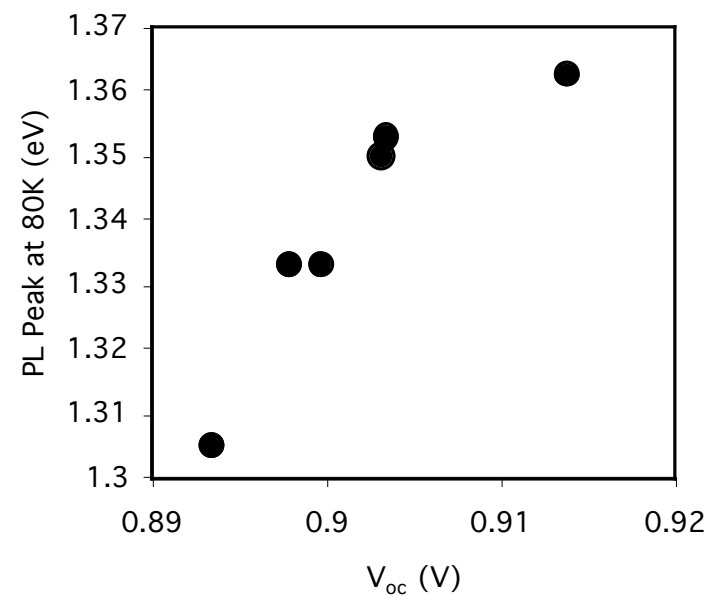

Fig. 3. The PL peak energy position measured at $80 \mathrm{~K}$ correlated to the $\mathrm{V}_{\text {oc }}$ for the samples in Figure 2. The higher the $\mathrm{V}_{\mathrm{oc}}$, the higher the peak-energy position.

the PL peak energy position increases with $\mathrm{V}_{\mathrm{oc}}$ and is independent of the substrate temperature (see Fig. 2). At low temperatures such as $80 \mathrm{~K}, \mathrm{PL}$ measured the radiative recombination energy of excited electron-hole pairs. In aSi:H materials, the peak energy position relates to the optical gap and the width of band tails. Deconvoluting the $\mathrm{PL}$ data to the bandgap and/or band-tail width is not the subject of this paper. The correlation of PL peak energy position with $\mathrm{V}_{\text {oc }}$ suggests that $\mathrm{V}_{\mathrm{oc}}$ increases qualitatively with increase of the bandgap of the $i$ layer. However, the non-linear relationship between PL peak energy and $V_{o c}$ at higher $\mathrm{V}_{\mathrm{oc}}$ weakens the argument.

Figure 4 shows the effect of the i-layer thickness on solar cell performance. The $i$-layer was grown at the condition that was optimized for hydrogen dilution with $R$ $=2.25$ at $150^{\circ} \mathrm{C}$. The three solar cells were completed at NREL. This experiment is to test the thickness dependence of $\mu \mathrm{c}-\mathrm{Si}$ growth that was reported by United Solar [15] in the solar cell. We found that $V_{o c}$ and $F F$ decrease with increasing thickness. Interestingly, the $V_{\text {oc }}$ for a solar cell just over $1 \mu \mathrm{m}$ thick is still quite good $(0.88$ $\mathrm{V}$ ), although the FF decreased dramatically. These HW results agree with the previous report PECVD solar cells by United Solar.

In all-HW $n-i-p$ solar cell fabricated at NREL, a $60-\AA$ higher $\mathrm{H}$-diluted amorphous silicon layer was inserted between the $i$ and $p$ layers and was found to help the solar cell performance [8]. We also used the same buffer layer and the same $p$ layer that were reported previously [9] for all the high $\mathrm{V}_{\text {oc }}$ solar cells at NREL.

Table I summarizes the optimized high- $\mathrm{V}_{\text {oc }}$ solar cells growth condition and performance. The first data show the $i$-layer deposition parameters. For the all-HW $n-i-p$ solar cells, the best initial high-voltage solar cell has a $V_{\text {oc }}$ of $0.941 \mathrm{~V}$, with $\mathrm{FF}$ of $0.749, \mathrm{~J}_{\mathrm{sc}}$ of $8.2 \mathrm{~mA} / \mathrm{cm}^{2}$, and efficiency (Eff.) of $5.8 \%$. High $\mathrm{V}_{\mathrm{oc}}$ solar cells, in general, are designed for the wide-gap top cell in the multijunction structure. Therefore, the i-layer is thin $(1800 \AA)$ and the

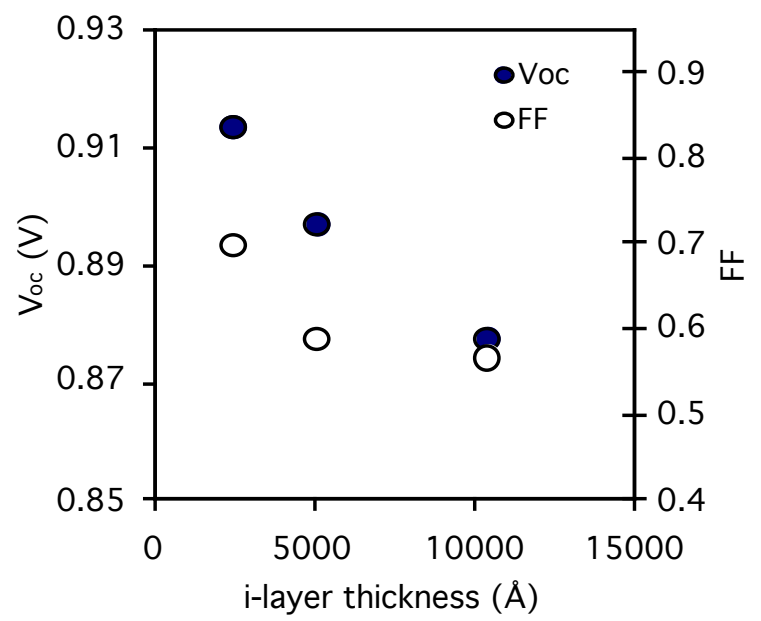

Fig. 4. $V_{o c}$ and FF dependence on the thickness of $i-$ layer at the optimized condition of $\mathrm{H}$-dilution.

short-circuit current density is low. To achieve high efficiency for this type of cell, we increase the i-layer thickness such that the efficiency is optimized. The best initial-efficiency solar cell has a $V_{\text {oc }}$ of $0.931 \mathrm{~V}$, FF of $0.708, \mathrm{~J}_{\mathrm{sc}}$ of $10.9 \mathrm{~mA} / \mathrm{cm}^{2}$, and Eff. of $7.2 \%$ optimized at $2500 \AA$. The stability test of those solar cells is under way. However, we do have light-soaking data on a solar cell with the $i$-layer grown close to the best high- $V_{\text {oc }}$ solar cell. This cell shows a degradation of $V_{\text {oc }}$ from 0.898 to 0.861 $\mathrm{V}$.

Table 1. Summary of High- $\mathrm{V}_{\mathrm{oc}}$ Solar Cells.

High- $\mathrm{V}_{\text {oc }}$ solar cell optimized $i$-layer process parameters

\begin{tabular}{|l|l|l|l|l|}
\hline & $\begin{array}{l}\mathrm{SiH}_{4} \\
(\mathrm{sccm})\end{array}$ & $\begin{array}{l}\mathrm{H}_{2} \\
(\mathrm{sccm})\end{array}$ & $\begin{array}{l}\mathrm{P} \\
(\mathrm{mT} \text { Torr })\end{array}$ & $\mathrm{T}_{\text {sub }}\left({ }^{\circ} \mathrm{C}\right)$ \\
\hline$i$-layer & 45 & 100 & 18 & 150 \\
\hline
\end{tabular}

High- $\mathrm{V}_{\mathrm{oc}}$ all-HW solar cell performance

\begin{tabular}{|l|l|l|l|l|}
\hline & $\mathrm{V}_{\text {oc }}(\mathrm{V})$ & $\mathrm{FF}$ & $\begin{array}{l}\mathrm{J}_{\mathrm{sc}} \\
\left(\mathrm{mA} / \mathrm{cm}^{2}\right)\end{array}$ & $\begin{array}{l}\text { Eff. } \\
(\%)\end{array}$ \\
\hline Best Initial $\mathrm{V}_{\text {oc }}$ & 0.941 & 0.749 & 8.2 & 5.8 \\
\hline Best Initial Eff. & 0.931 & 0.708 & 10.9 & 7.2 \\
\hline
\end{tabular}

Light-soaking results from similar $i$-layer to high- $\mathrm{V}_{\mathrm{oc}}$ cell

\begin{tabular}{|l|l|l|l|l|}
\hline Initial & 0.898 & 0.661 & 10.31 & 6.1 \\
\hline After 1000 hour & 0.861 & 0.591 & 9.65 & 4.9 \\
\hline
\end{tabular}

High- $V_{\text {oc }}$ NREL-USSC hybrid solar cell performance

\begin{tabular}{|l|l|l|l|l|}
\hline & $\mathrm{V}_{\mathrm{oc}}(\mathrm{V})$ & $\mathrm{FF}$ & $\begin{array}{l}\mathrm{J}_{\mathrm{sc}} \\
\left(\mathrm{mA} / \mathrm{cm}^{2}\right)\end{array}$ & $\begin{array}{l}\text { Eff. } \\
(\%)\end{array}$ \\
\hline Best Initial $\mathrm{V}_{\mathrm{oc}}$ & 0.971 & 0.717 & 9.63 & 6.70 \\
\hline Best Initial Eff. & 0.962 & 0.716 & 10.12 & 6.97 \\
\hline
\end{tabular}


The last data show the performance on the collaborated solar cells between NREL and United Solar. Using the same $i$-layer that was optimized for HW highVoc solar cells, the best initial high voltage solar cell has $\mathrm{V}_{\mathrm{oc}}$ of $0.971 \mathrm{~V}$, with FF of $0.717, \mathrm{~J}_{\mathrm{sc}}$ of $9.63 \mathrm{~mA} / \mathrm{cm}^{2}$, and Eff. of $6.70 \%$. And the best initial efficiency solar cell has a $\mathrm{V}_{\text {oc }}$ of $0.962 \mathrm{~V}$, FF of $0.716, \mathrm{~J}_{\mathrm{sc}}$ of $10.12 \mathrm{~mA} / \mathrm{cm}^{2}$, and Eff. of $6.97 \%$.

\section{CONCLUSIONS}

In summary, high-performance, high $\mathrm{V}_{\text {oc }}(0.941 \mathrm{~V}$ in all-HW and $0.971 \mathrm{~V}$ in hybrid) a-Si:H solar cells have been fabricated. These values are the best results to date of $V_{o c}$ using the HWCVD technique. The $V_{\text {oc }}$ improvement was achieved by incorporating materials grown with $\mathrm{H}$-dilution close to the phase transition from amorphous to microcrystalline silicon in the $i$-layer. The $\mathrm{V}_{\mathrm{oc}}$ is sensitive to the hydrogen dilution near the optimized condition. We also found that a low substrate temperature of $150^{\circ} \mathrm{C}$ for the $i$-layer was also essential. We believe that the widegap $i$-layer is the key for improving of $V_{\text {oc }}$. Increasing $i$ layer thickness from 1800 to $10,000 \AA$ at the optimized $R=$ 2.25 causes $\mathrm{V}_{\text {oc }}$ to decrease.

\section{ACKNOWLEDGEMENTS}

The authors are thankful for helpful discussions with Brent Nelson, Yueqin Xu, Richard Crandall, Harv Mahan, and Howard Branz. This work is supported by the U.S. Department of Energy under Contract No. DE-AC3699G010337, at United Solar by NREL Thin-film Partnership Program Subcontract \# ZAK-8-17619-09 and at NUC by NREL Thin-film Partnership Program Subcontract \# ADJ-1-30630-09.

\section{REFERENCES}

1. J. Yang, A. Banerjee, and S. Guha; "Triple-junction amorphous silicon alloy solar cell with $14.6 \%$ initial and $13.0 \%$ stable conversion efficiencies" Appl. Phys. Lett. 70 1997, pp. 2975-2977.

2. L. Jiang, J.H. Lyou, S. Rane, E. A. Schiff, Q. Wang, and Q. Yuan; "Open-circuit voltage physics in amorphous silicon solar cells," Mat. Res. Soc. Proc. Vol. 609, 2000, pp. A18.1-A18.3.11.

3. J.M.A. Pearce, R.J. Koval, A.S. Ferlauto, R.W. Collins, C.R. Wronski, J. Yang, and S. Guha; "Dependence of open-circuit voltage in hydrogenated protocrystalline silicon solar cells on carrier recombination in $\mathrm{p} / \mathrm{i}$ interface and bulk regions ". Appl. Phys. Lett. 77, 2000, pp. 3093-3096.

4. N.T. Tran, F.R. Jeffrey, and D.J. Olsen. "Effects of carbon grading at the $\mathrm{p} / \mathrm{i}$ interface on the open circuit voltage of $p-i-n$ and $n-i-p$ amorphous silicon solar cells", in Amorphous Silicon Semiconductors - Pure and Hydrogenated. 1987. Mat. Res. Soc. Proc. 1987, p.545.
5. Y.M. Li, F. Jackson, L. Yang, B.F. Fieselmann, and L. Russell. "An exploratory survey of p-layers for a-Si:H solar cells ", Mat. Res. Soc. Proc. Vol 336, 1994, pp. 663-668.

6. H. Tanaka, N. Ishiguro, T. Miyashita, N. Yanagawa, M. Sadamoto, M. Koyama, K. Miyachi, Y. Ashida, and N. Fukuda; "Improvement of p-i buffer layer properties by hydrogen plasma treatment and its applications to pin a-Si:H solar cells " in 23rd IEEE Photovoltaic Specialists Conference. 1993, pp. 811-815.

7. Guha, J. Yang, P. Nath, and M. Hack, "Enhancement of open circuit voltage in high efficiency amorphous silicon alloy solar cells," Appl. Phys. Lett. 49, 1986, pp. 218-219.

8. Q. Wang, E. Iwaniczko, Yueqin Xu, B. Nelson, and H. Mahan, "Assessment of Intrinsic-layer growth Temperature to High-deposition-Rate a-Si:h n-i-p Solar Cells deposited by Hot-Wire CVD "Mat. Res. Soc. Proc. Vol 557 1999, pp.163-168.

9. Q. Wang, E. Iwaniczko, B.P. Nelson. Y.Q. Xu, A.H. Mahan, R.S. Crandall, and H.M. Branz; "Efficient High Deposition Rate All-Hot-Wire Hydrogenated Amorphous Silicon nip Solar Cells "in 28th IEEE Photovoltaic Specialists conference. 2000, pp. 717720.

10. S. Bauer, W. Herst, B. Schroeder, and H. Oechsner; "A-Si:H solar cells using the hot-wire technique- how to exceed efficiencies of $10 \%$." in 26th IEEE PV Spec. Conf., 1997 p.719-722.

11. A.H. Mahan, R.C. Reedy Jr., E. Iwaniczko, Q. Wang, B.P. Nelson, Y.X. Xu, A. C. Gallagher, H.M. Branz, R.S. Crandall, J. Yang, and S. Guha; "H out-diffusion and device performance in $n-i-p$ solar cells utilizing high temperature hot wire a-Si:H i-layers "Mat. Res. Soc. Proc., Vol. 507, 1998. pp.119-224.

12. S. Morrison and A. Madan; "Deposition of devicequality amorphous and microcrystalline silicon films wth a new "hot wire" CVD technique "in 28th IEEE Photovoltaic Specialists Conference. 2000, pp. 837 840.

13. B.P. Nelson, Q. Wang, E. Iwaniczko, A.H. Mahan, and R.S. Crandall; "The influence of electrons from the filament on the material properties of hydrogenated amorphous silicon growth by the hotwire chemical vapor deposition technique "Mat. Res. Soc. Proc., Vol 507, 1998, pp. 927-922.

14. G.Z. Yue, J. D. Lorentzen, J. Lin, D.X. Han, and Q. Wang, "Photoluminescence and Raman Studies in Thin-Film materials: Transition from Amorphous to Microcrystalline Silicon "Appl. Phys. Lett. 67, 1999, pp. 3468-3471.

15. J. Yang, K. Lord, S. Guha, and S. R. Ovshinsky, "Amorphous silicon alloy solar cells near the threshold of amorphous-to-microcrystalline transition," Mat. Res. Soc. Symp. Proc. 609, 2000, pp. A 15.4.1 - A 15.4.6. 


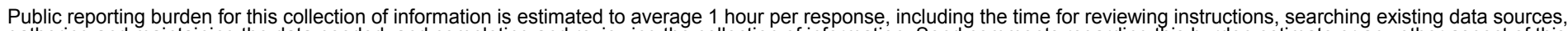

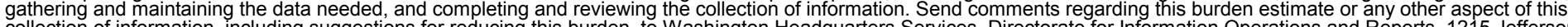
Davis Highway, Suite 1204, Arlington, VA 22202-4302, and to the Office of Management and Budget, Paperwork Reduction Project (0704-0188), Washington, DC 20503.

\begin{tabular}{|l|l|l|l|}
\hline 1. AGENCY USE ONLY (Leave blank) & $\begin{array}{l}\text { 2. REPORT DATE } \\
\text { May } 2002\end{array}$ & $\begin{array}{l}\text { 3. REPORT TYPE AND DATES COVERED } \\
29^{\text {th }} \\
\text { IEEE PVSC-Conference Paper } \\
\text { May 20-24 2002 }\end{array}$ \\
\hline
\end{tabular}

4. TITLE AND SUBTITLE Wide-Gap Thin Film Si N-I-P Solar Cells Deposited by Hot-Wire CVD: Preprint

6. Author(S)

Q. Wang, ${ }^{1}$ E. Iwaniczko, ${ }^{1}$ J. Yang, ${ }^{2}$ K. Lord, ${ }^{2}$ S. Guha, ${ }^{2}$ K. Wang, ${ }^{3}$ and D. $\operatorname{Han}^{3}$
5. FUNDING NUMBERS PVP24101

8. PERFORMING ORGANIZATION REPORT NUMBER

10. SPONSORING/MONITORING AGENCY REPORT NUMBER

NREL/CP-520-31474

11. SUPPLEMENTARY NOTES

12a. DISTRIBUTION/AVAILABILITY STATEMENT

National Technical Information Service

12b. DISTRIBUTION CODE

U.S. Department of Commerce

5285 Port Royal Road

Springfield, VA 22161

13. ABSTRACT (Maximum 200 words): High-voltage wide bandgap thin-film Si $n-i-p$ solar cells have been made using the hot-wire chemical vapor deposition (HWCVD) technique. The best open-circuit voltage $\left(\mathrm{V}_{\text {oc }}\right)$ has exceeded $0.94 \mathrm{~V}$ in solar cells using HWCVD in the entire $n-i-p$ structure. $A V_{\text {oc }}$ of $0.97 \mathrm{~V}$ has been achieved using HWCVD in the $n$ and $i$ layers and plasma-enhanced (PE) CVD for the $p$ layer. The high voltages are attributed to the wide-gap i layer and an improved p/i interface. The wide-gap $i$ layer is obtained by using low substrate temperatures and sufficient hydrogen dilution during the growth of the i layer to arrive at the amorphous-to-microcrystalline phase transition region. The optical band gap ( $\left.E_{04}\right)$ of the $\mathrm{i}$ layer is found to be $1.90 \mathrm{eV}$. These high-voltage cells also exhibit good fill factors exceeding 0.7 with short-circuitcurrent densities of 8 to $10 \mathrm{~mA} / \mathrm{cm}^{2}$ on bare stainless steel substrates. We have also carried out photoluminescence (PL) spectroscopy studies and found a correlation between $\mathrm{V}_{\mathrm{oc}}$ and the $\mathrm{PL}$ peak energy position.

14. SUBJECT TERMS: PV; wide-gap thin film; hot-wire chemical vapor deposition (HWCVD); 15. NUMBER OF PAGES open circuit voltage; plasma-enhanced (PE); short-circuit-current densities; photoluminescence (PL);

16. PRICE CODE

17. SECURITY CLASSIFICATION OF REPORT Unclassified
18. SECURITY CLASSIFICATION OF THIS PAGE Unclassified
19. SECURITY CLASSIFICATION OF ABSTRACT Unclassified
20. LIMITATION OF ABSTRACT UL

NSN 7540-01-280-5500

Standard Form 298 (Rev. 2-89) Prescribed by ANSI Std. Z39-18 